\title{
Leaching losses of main nutrients by incorporating organic fertilisers into light texture soils Haplic Luvisol
}

\author{
Auksė Burakova ${ }^{\dagger}$, Eugenija Bakšiene \\ Lithuanian Research Centre for Agriculture and Forestry, Vokè Branch, Žalioji sq. 2, Vilnius, LT-02232, Lithuania
}

\begin{abstract}
The aim of this work was to show that fertilization of lightly structured soils (Haplic Luvisol), according to the principles of sustainable agriculture can facilitate achieving more valuable results with lower nutrient leaching losses. The research was performed in stationary concrete cylindrical lysimeters ( $\mathrm{n}=24,1.35 \mathrm{~m}$ depth) plots in were filled the Haplic Luvisol sandy loam ( $\mathrm{n}=12$, surface area $\left.1.75 \mathrm{~m}^{2}\right)$ and loamy sand $(\mathrm{n}=12$, surface area $1.75 \mathrm{~m}^{2}$ ) soil, typical to the Eastern Lithuanian area. Scheme of the experiment: 1) control (no fertilizer), 2) NPK fertilizers (Provita, phosphorite powder and potassium magnesia), 3) $40 \mathrm{t} / \mathrm{ha}$ sapropel and 4) $60 \mathrm{t} / \mathrm{ha}$ manure. Fertilization with $40 \mathrm{t} / \mathrm{ha}$ sapropel was found to significantly reduce nitrate leaching losses in sandy loam and loamy sand soils, compared to other applied fertilizers. 60 t/ha manure tended to reduce potassium leaching content in sandy loam soil. The highest phosphorus leaching losses found in two types of soils with incorporated organic NPK fertilizer (Provita, phosphorite powder and potassium magnesia).
\end{abstract}

Keywords: Fertilizer efficiency, Infiltration, Leaching, Light texture soil, Lysimeter

\section{Introduction}

Sustainable agriculture relies on natural processes in soil. Soil fertility is of particular importance as without the use of synthetic mineral fertilisers, the yields and success of all economic activities directly depend on the condition of soil [1]. Soils in many European countries are not contrasting but they can be characterised by typical percolating moisture regime [2]. Percolated precipitation influences the chemical composition of groundwater and river runoff. Lithuanian soils, and in particular those in Eastern Lithuania with low humus content $(0.29-1.10 \%$ SOC) do not ensure high crop productivity. There is a need for the latter to be supplied with additional nutrients in the form of organic fertilizers. The use of organic fertilizers for agricultural crop fertilization increases both the organic carbon accumulation in the arable soil layer, and the likelihood of leaching of biogenic elements released during the application of organic fertilizers into deeper soil layers [3, 4]. Nitrogen, phosphorus and many other elements from organic fertilizers is the slow-release and organically bound, this process during the amount of precipitation have less leaching losses. During a heavy rainfall we have more probability to have nutrients losses. Phosphorus combined with nitrogen in soil is one of the most limiting factors in plant production. Recently, the intensive use of these elements in agriculture has increased the loss of $\mathrm{N}$ and $\mathrm{P}$, which has a significant negative impact on water quality [5].

Previous investigations have shown that organic farming is generally associated with significantly higher levels of biological activity and a higher content of soil organic matter [6]. Organic farming in productive areas is the least damaging farming system for wildlife conservation [7]. Some argue that they find no evidence that nitrogen leaching losses will be reduced through the introduction of organic farming practices [8]. Others conclude that organic farming produces lower or similar levels of nitrate leaching compared to integrated or conventional agriculture. The greatest risk is faced when $\mathrm{N}$ released from organic fertilizers does not coincide with the level of uptake by crops or when $\mathrm{N}$ fertilization rates start to exceed those calculated (based on known yields) [9].

Leaching losses of biogenic elements are related not only to the agronomic use of soil but also to climatic factors - the intensity of precipitation, temperature regime, evaporation condition, vegetation cover and soil moisture content as well as the thermal regime (number of days with negative air temperature and mean daily temperature) [10-12].

Long-term lysimetric studies (1972-1995) showed that in Lithuanian
This is an Open Access article distributed under the terms of the Creative Commons Attribution Non-Commercial License (http://creativecommons.org/licenses/by-nc/3.0/) which permits unrestricted non-commercial use, distribution, and reproduction in any medium, provided the original work is properly cited.

Copyright (C) 2021 Korean Society of Environmental Engineers
Received April 21, 2020 Accepted September 02, 2020

${ }^{\dagger}$ Corresponding author

Email: aukse.burakova@lammc.lt

Tel: +370-683-646-28

ORCID: 0000-0001-6605-689X 
soils nitrate cations (about 90-98\%) are most abundantly leached of all nitrogen forms, and only a small amount is leached in the form of ammonium anions [13]. Their content is concentrated in the arable soil layer $(0-30 \mathrm{~cm})$, which, in case of abundant and intense precipitation (especially when it amounts to $30 \mathrm{~mm}$ or more in a short time), easily leaches into the subsoil or deeper layers [14-16]. According to the research conducted by Yadav [17], about $20 \%$ of nitrate nitrogen in the root zone is leached into groundwater each year along with precipitation, and its accumulation amounts up to $68 \%$.

Phosphorus leaching is significantly influenced by the amount of applied organic fertilizers and the $\mathrm{pH}$ condition of the soil, which determines the phosphorus consumption during crop growth [18].

Manure fertilization tends to reduce the amount of potassium leaching, due to its ability to release nutrients gradually, and the soil is not depleted of potassium over several years [19]. Potassium elements are much more efficiently used in moist soil, while the efficiency of fertilizers applied is reduced and, conversely, in the case of low organic matter soils with lower moisture content, the applied fertilizers are more effective; thus, the losses are lower in sandy loam compared to light loam soils with more numerous clay particles [20-22].

According to Plotnikov et al. [23] and also Ivanova et al. [24] researchers, the nitrogen mineralisation rate of sapropel fertilizer is slower, resulting in low nitrate loss.

One of the most important principles of organic farming is to create the plant nutrient cycle on the farm, which is as closed as possible to avoid the unwanted loss of elements from the topsoil layer. Organic fertilizers introduced into organic farming systems are designed to enhance soil fertility for a number of purposes: to protect and improve the physical condition of soil, achieve good soil buffering capacity, minimize nutrient losses and obtain a good quality of yields [25]. Organic fertilisers, especially NPK mixture (Provita, phosphorite powder and Patentkali), and sapropel are used to fertilize nutrient migration. Many articles on scientific experiments describe the application of phosphorus powder in acidic soils or the addition of saline solutions to improve the availability of phosphorus to plants. There is limited data on the action of phosphorite powder in neutral soils and leaching into deeper soil layers. Sapropel fertilizers are not popular as they are contaminated with heavy metals from other countries. Large amounts of organic sapropels are suitable for organic fertilizer extraction in Lithuania, Latvia, Estonia, Belarus, Canada, Russia and other countries. According to preliminary estimates, about 1.5-2 billion $\mathrm{m}^{3}$ of pure sapropel has been detected in the lakes of the Republic of Lithuania and it is the largest source of ecological sapropel available in the European Union.

The aim of this lysimetric experiment is to demonstrate that it is possible to achieve excellent yields without mineral fertilizers by fertilizing light textured soils (Haplic Luvisol) in line with the principle of sustainable agriculture, which restores the natural biological activity of soil, increases the formation of organic matter and reduces nutrient leaching.

\section{Materials and Methods}

\subsection{Experimental Site}

The experiments were performed at Vokè Branch of the Lithuanian
Research Centre for Agriculture and Forestry (LRCAF) using the lysimetric equipment consisting of a cylindrical concrete structure. For the experimental purposes, the number of lysimeter plots was 24. The plots were filled with Haplic Luvisol soil characteristic of the region of Eastern Lithuania: 12 plots with sandy loam and 12 plots loamy sand. The lysimeter surface area was $1.75 \mathrm{~m}^{2}$ and the test soil layer was $1.35 \mathrm{~m}$. Experimental design was as follows: 1) no fertilizer (control); 2) NPK organic fertilizer mix (Provita, phosphorite powder, potassium magnesia); 3) sapropel $40 \mathrm{t} / \mathrm{ha}$; and 4) cattle manure $60 \mathrm{t} / \mathrm{ha}$. The four treatments were arranged in a randomized design with 3 replicates.

The rates for sapropel and manure fertilizer are presented in natural matter and the amount of incorporated elements is calculated in dry matter.

The experiments used organic fertilizers such as Provita, phosphorite powder and potassium magnesia (Patentkali), certified in 2006 by PI Ekoagros for organic production farms. Provita is a fertilizer manufactured from processed pig bristles according to a special technology that removes moisture, chops bristles and compresses them into pellets. Fertilizer composition: $\mathrm{N}_{\text {sum }}-14.0 \%$. The fertiliser is of neutral reaction and therefore does not acidify soil. Phosphorite powder is a source of phosphorus for plants obtained by grinding phosphorites. It contains $20 \% \mathrm{P}_{2} \mathrm{O}_{5}$. Potassium magnesium sulphate (Patentkali) is a source of potassium for plants in organic farms. The fertilizer is produced from natural marine sediments. They contain $30 \% \mathrm{~K}_{2} \mathrm{O}$.

For the experimental purposes, the plants were grown in a four-field crop rotation: spring barley (Hordeum vulgare L.) - potatoes (Solanum tuberosum L.) - peas (Pisum sativum L.).

All agrotechnical operations were performed manually. The spring barley and peas were sown in the third ten-day period of April. The seeding rate was $200 \mathrm{~kg} / \mathrm{ha}$. Inter rows $-2 \mathrm{~cm}$. The potatoes were planted in the third ten-day period of April (9 $\mathrm{u}$. per lysimeter).

The fertilizer rates for cereals and potatoes were applied in spring; according to the experimental scheme they were incorporated in the lysimeters 2-4 days before sowing or planting. Sapropel and manure were incorporated during the first year of the study. The following year, their effects were monitored. The lysimeter plots were fertilized with NPK organic fertilizers every year in spring, 2-4 days before sowing / planting.

The recommended NPK organic fertilizer rates for plant fertilization were used as follows: $\mathrm{N}_{50} \mathrm{P}_{50} \mathrm{~K}_{50}$ for barley; $\mathrm{N}_{60} \mathrm{P}_{60} \mathrm{~K}_{60}$; and $\mathrm{N}_{0} \mathrm{P}_{50} \mathrm{~K}_{50}$ for peas.

All chemical parameters were determined in the Agrochemical Research Laboratory of the Lithuanian Research Centre for Agriculture and Forestry. In cattle manure, sapropel $\mathrm{N}_{\text {total }}$ was determined by the Kjeldahl $\mathrm{N}$ distiller in accordance with the standard EN 13654-1:2012 (Soil improvers and growing media Determination of nitrogen. Modified Kjeldahl method), $\mathrm{P}$ and in organic fertilizer (sapropel, manure) were determined in aqua regia by spectrometric method according to EN 13650:2001 (Soil improvers and growing media - Extraction of aqua regia soluble elements). Total $\mathrm{K}$ in crop yield and organic fertilizers (manure, sapropel) were determined according to EN 13650:2006 (Soil improvers and growing media - Extraction of aqua regia soluble elements).In filtrated water: nitrates $\left(\mathrm{NO}_{3}\right)$ by LST EN ISO-13395:2000 standard 
flow analysis (FIA) (Water quality. Nitrite nitrogen $\left(\mathrm{NO}_{2}{ }^{-}\right)$, nitrate nitrogen $\left(\mathrm{NO}_{3}{ }^{-}\right)$and their sum flow analysis (CFA and FIA) and spectrometric detection). Potassium determined by LST ISO 99643:1998 standard (atomic absorption spectrometry method), P in spectrometric, K according to ISO 99643:1998 (Water quality - Determination of sodium and potassium - Part 3: Determination of sodium and potassium by flame emission spectrometry) using flame emission photometer PFP7 (Jenway, UK).

\subsection{Water filtration}

The amount of filtrate were calculated for separate months, seasons and years. Season length of spring (March-May), summer (JuneAugust) and autumn (September-November) matched the calendar periods of a year. Estimation of atmospheric precipitation in winter corresponded with the accounts of filtration during this period (precipitation amount in December of the current year (n) was summed up with precipitation amount of January and February of the following year $(n+1)$. Such calculation is based on the temperature regime of winter period, because at temperatures below $0^{\circ} \mathrm{C}$ solid precipitation occurs, which takes a liquid for only at positive air temperatures, and the infiltration can start much later than the precipitation occurrence. The amount of atmospheric precipitation filtrate per year was calculated from 1 March of the current year till last day of February of the following year (12 months).

Infiltrated water was collected in 20-25 L glass bottles from each lysimeter separately at the end of every month.

Infiltrated water sample is taken monthly for $2.5 \%$ of the lysimetric amount of water collected from each glass bottles. The leachate average of elements concentrations were calculated for each treatment. Nitrate concentration $\left(\mathrm{NO}_{3}^{-}\right)$in lysimetric water was determined monthly, concentrations of phosphorus and potassium - once per season. The leachate concentrations of the elements were calculated in $\mathrm{mg} / \mathrm{L}$ and infiltrate amount calculated $-\mathrm{L} \mathrm{m}^{2}$ for separate months, seasons (every three months) and years. Infiltrate samples are taken monthly, 2.5\% of the lysimetric amount of water collected from each treatment glass bottles. The infiltration rate (mg/ha) of the substances was calculated according to the formula as follows in Eq. (1) [26];

$$
\mathrm{NL}=\mathrm{VT} \times \mathrm{C}_{\mathrm{e}}
$$

where $\mathrm{C}_{\mathrm{e}}$ is concentration of leached element $(\mathrm{mg} / \mathrm{L})$; VT is the total volume of infiltrated water per hectare over a given period (month, season) (L).

The total volume of leachate (VT) is determined as follows in Eq. (2);

$$
V T=\frac{V B \times 1000}{A C}
$$

where VB is the volume of water infiltrated from the lysimeter plot (for a given month or season) (L), and AC is the lysimeter plot area $\left(\mathrm{m}^{2}\right)$.

\subsection{Meteorological Review}

For the evaluation of meteorological data and condition, the data provided by Vilnius meteorological station was used.

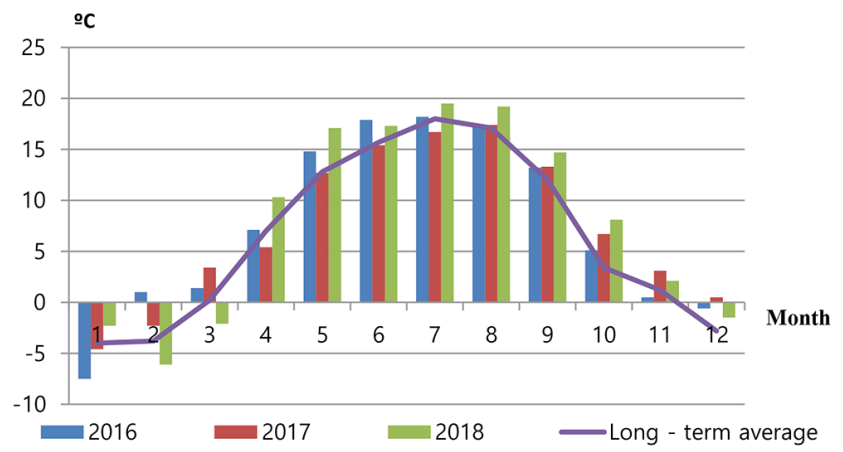

Fig. 1. Temperature distribution compare to the Long term average from 2016.

Lithuania's climate is transitional between mid-latitude oceanic and continental. At present, the average air temperature is about $6.9^{\circ} \mathrm{C}$ and compared to the climatological standard normals of 2011-2016 and 1981-2010 it shows a tendency for temperature risen as much as $0.7^{\circ} \mathrm{C}$, indicating marked warming of the climate (Fig. 1). Since 1981, the observations of temperature changes have evidenced an increase in the average annual air temperature of 2015 equal to as much as $8.3^{\circ} \mathrm{C}$.

In the recent period, meteorological observations suggest that global warming and seasonal distribution of precipitation may alter the nature of rainfall infiltration in soil. The tendency for an increase in precipitation has been recorded in all regions of the Baltic States [27]. The average annual rainfall in Lithuania is about $695 \mathrm{~mm} \mathrm{[28].}$

The average precipitation during the experiment increased annually and separately for each season. A clearer distribution of minimum and maximum precipitation values is obtained: the year of excess moisture changed to a very dry year (Table 1). The most pronounced were the summer and autumn periods; during each year of the experiment in those seasons, the rainfall was the highest compared to the annual rainfall (Table 1). The uneven distribution of seasonal precipitation over the three-year period was observed, with the highest recorded precipitation in 2017, during which the rainfall exceeded the average multi-annual value (948 $\mathrm{mm}$ ).

\subsection{Statistical Methods}

The Microsoft Office Excel software package was used to fill in the data, determine correlation coefficients (r) and relationships, and describe them.

The nutrient leaching data was evaluated by analysis of variance (ANOVA) using the Fisher's test from the software package SELEKCIJA [29].

The differences between applications were calculated by the least significant difference $\left(\mathrm{LSD}_{05}\right)$ at $95 \%$ confidence level.

\section{Results and Discussion}

\subsection{Atmospheric Precipitation Infiltration in the Lysimeters Soil}

The physical and chemical properties of soil itself should be borne 
in mind, when it comes to precipitation and its percolation into deeper soil layers. When calculating the correlations between precipitation and percolated water each year, a very weak relationship between the two variables ( $r=0.03-0.32$ ) could be observed. Thus, it can be argued that the amount of precipitation is not the only factor that determines the precipitation infiltration into the deeper layers of soil. Kim et al. [21] and Zhang, Wang and Wang [12] agree that the factors important for infiltration are precipitation intensity; vegetation cover, soil moisture content and the thermal regime (number of negative air temperature days and mean daily temperature [10].

Data on the seasonal distribution of leaching shows that almost in all the cases most intensive leaching is recorded in the spring season and in the late autumn, when the soil surface without agricultural crops (Table 1). Proportions of winter and spring leaching are very close (1.3\% difference) and winter leaching is less intensive $(2-8 \%)$ in sandy loam soil, only in loamy sand Haplic Luvisols soil winter leaching is more intensive (6-15\%) . Higher infiltration rates could be observed in sandy loam due to low organic matter content and light textured soil that did not retain water molecules on the soil surface. During the study period, the average infiltration in sandy soils was 7 to $19 \%$ higher compared to that of the control, depending on hydrothermal conditions (Fig. 2 (a), (b), (c)). In terms of individual seasons, the summer period was distinguished by the extremely low infiltration rates in the two types of soils (Table 2). The precipitation amount in summer (36\% of the annual amount) is higher than in spring (16\%) (Table 1). Such distribution of precipitation is favourable for the development and yielding of agricultural plants, it also reduces the infiltration in soil because in summer the evaporation is enhanced and soil is covered with vegetation. According to the data of 2016-2018 the average infiltration in summer made up $11 \%$ of the annual infiltrated volume in sandy soil, and in loamy sand made up 5-6\% of annual infiltrated volume. Most frequently (74\% probability) the infiltration ceases in summer time resulting from the intensive use of water by plants and hydrothermal regime. But, with increasing rainfall amount during summer time can the infiltration could resume (42\% probability) [30, 31].

Higher levels of organic matter and added organic fertilizers in loamy sand soil control the overall stability, which reduces nutrient leaching and improves water sorption [32]. Thus, the loamy sand soil showed lower infiltration of between 3 and $20 \%$ of the annual rate on average, compared to the infiltration for sandy loam (Table 2). In terms of the annual amount of water infiltrated, the significantly lowest infiltration was determined in loamy sand soil

Table 1. Atmospheric Precipitation of Seasons (mm) with Long-Term Average Amount

\begin{tabular}{|c|c|c|c|c|c|c|c|}
\hline \multirow{2}{*}{ Seasons } & \multicolumn{3}{|c|}{ Average precipitation amount (mm) } & \multirow{2}{*}{$\begin{array}{c}\text { Long-term } \\
2016\end{array}$} & \multicolumn{2}{|c|}{ average in 1981-2016 } & \multirow{2}{*}{$\begin{array}{l}\text { Amount of precipitation(mm) } \\
\text { during the seasons }\end{array}$} \\
\hline & 2016 & 2017 & 2018 & & 2017 & 2018 & \\
\hline Spring & 132 & 144 & 79 & 128 & 107 & 122 & 355 \\
\hline Summer & 184 & 377 & 212 & 280 & 350 & 293 & 773 \\
\hline Autumn & 204 & 271 & 92 & 118 & 158 & 137 & 567 \\
\hline Winter & 133 & 154 & 158 & 114 & 157 & 173 & 445 \\
\hline Amount per hidrological Year & 652 & 948 & 540 & 640 & 772 & 725 & \\
\hline
\end{tabular}

Table 2. Water Filtration $(\mathrm{L} / \mathrm{m})$ Amount in Differently Fertilized Soils

\begin{tabular}{|c|c|c|c|c|c|c|}
\hline \multirow{2}{*}{ Treatment } & \multicolumn{4}{|c|}{ Season of the year } & \multicolumn{2}{|c|}{ Average per hydrological year } \\
\hline & Spring & Summer & Autumn & Winter & $\mathbf{L} / \mathbf{m}^{2}$ & $\%$ \\
\hline \multicolumn{7}{|l|}{ Sandy loam } \\
\hline Control & 109,7 & 36,4 & 114,9 & 100,7 & 361,7 & 100 \\
\hline NPK & $127,7^{*}$ & 47,5 & $129,9^{*}$ & 125,9 & $430,2^{*}$ & 119 \\
\hline $40 \mathrm{t} /$ ha sapropel & 120,5 & 49,4 & $124,7^{*}$ & 117,6 & $412,2^{*}$ & 114 \\
\hline $60 \mathrm{t} /$ hamanure & 119,8 & 27,6 & $122,2^{*}$ & 116,6 & 386,2 & 107 \\
\hline $\mathrm{LSD}_{05}$ & 14,5 & 18,47 & 7,6 & 25,03 & 24,7 & \\
\hline \multicolumn{7}{|l|}{ Loamy sand } \\
\hline Control & 107,2 & 19,8 & 103,4 & 119,8 & 350,7 & 100 \\
\hline NPK & 104,2 & 21,5 & 100,1 & 117 & 342,7 & 98 \\
\hline 40 t/ha sapropel & 103,8 & 21,1 & 107 & 120,8 & 352,6 & 101 \\
\hline $60 \mathrm{t} /$ hamanure & 107,7 & 15,5 & 92,1 & 114,4 & $329,7^{*}$ & 94 \\
\hline $\mathrm{LSD}_{05}$ & 10,6 & 9,7 & 13,8 & 5,08 & 16,14 & \\
\hline
\end{tabular}

NPK - Provita, phosphorite powder, potassium magnesia (Patenkali) fertilizers

$\mathrm{LSD}_{05}$-leastsignificantdifferences $(\mathrm{P}<0.05)$.

* significant differences compare with control (no-fertilised) treatment. 

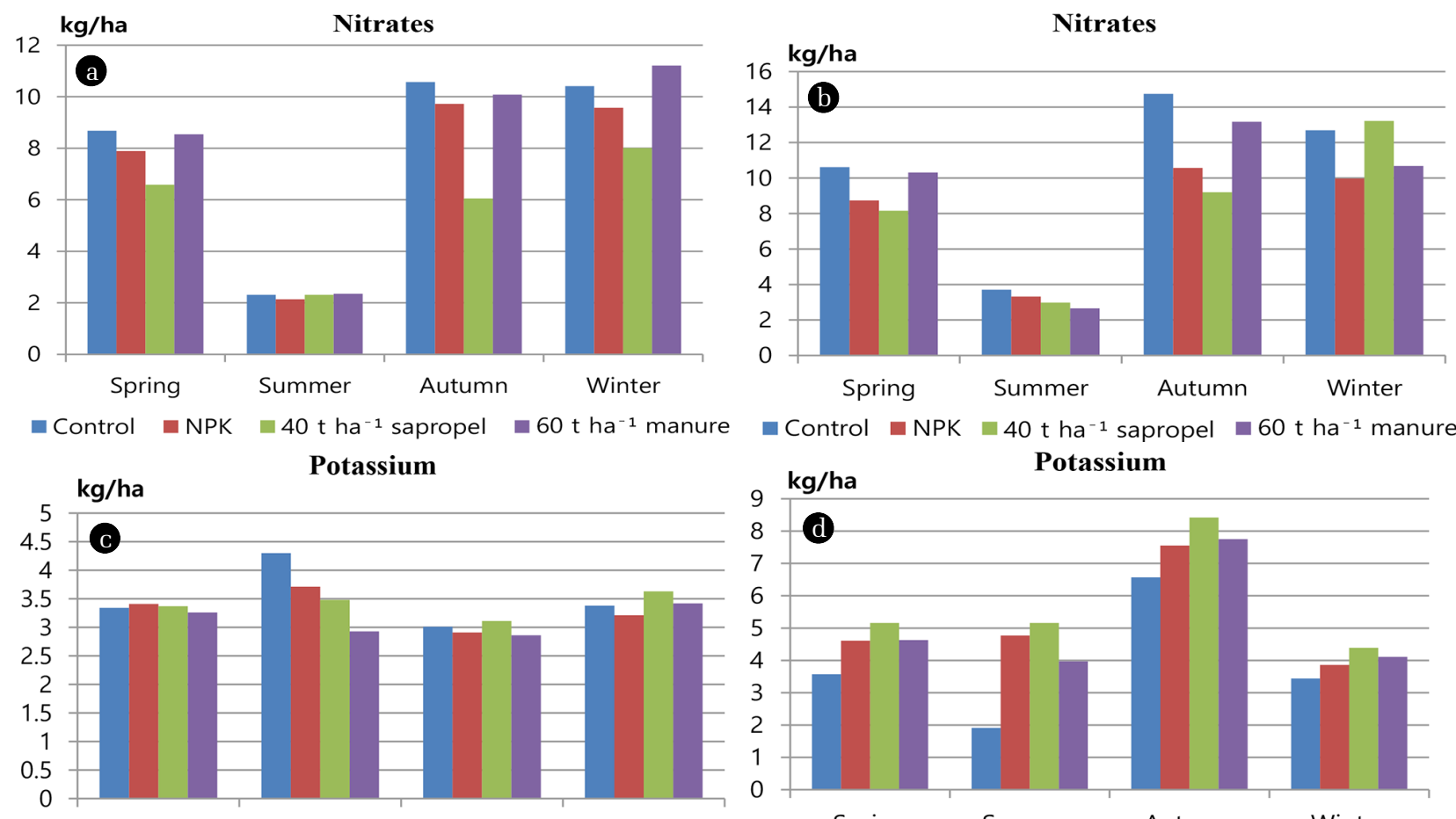

- Control $\square$ NPK $\square 0 \mathrm{t} \mathrm{ha}^{-1}$ sapropel $\square 60 \mathrm{t} \mathrm{ha}^{-1}$ manure

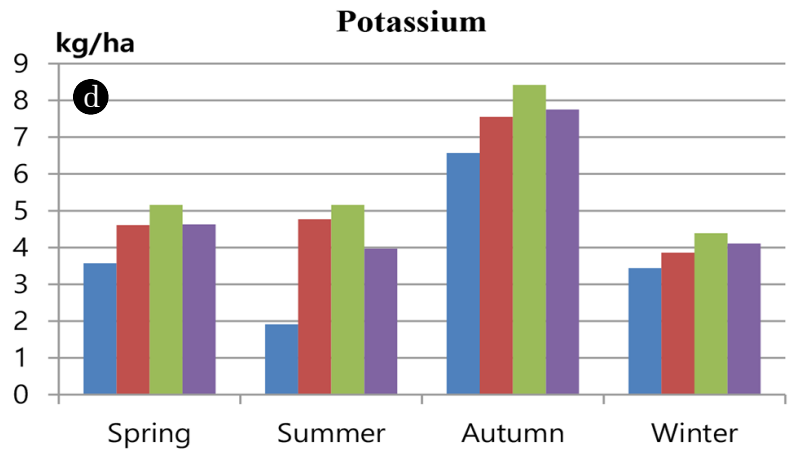

- Control NPK $40 \mathrm{t} \mathrm{ha}^{-1}$ sapropel $60 \mathrm{t} \mathrm{ha}^{-1}$ manure
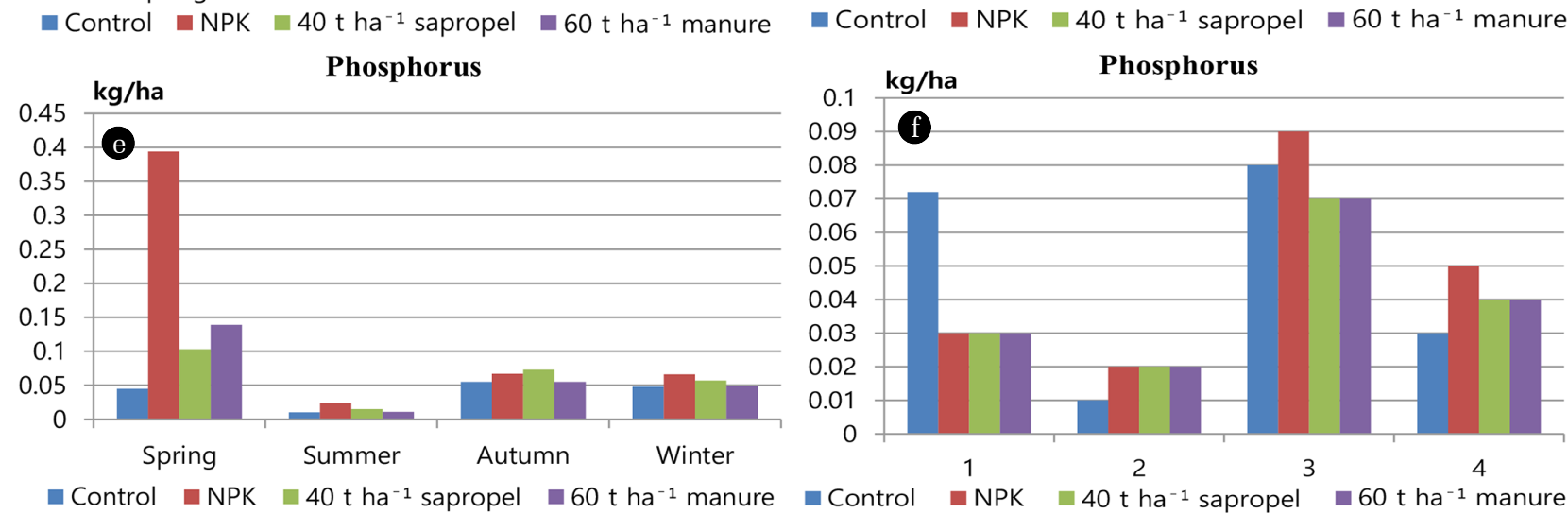

Fig. 2. The seasonal elements(NO3 ((a), (b)); $\mathrm{P}((\mathrm{c}),(\mathrm{d})) ; \mathrm{K}((\mathrm{e}),(\mathrm{f}))$ leaching dynamics (kg/ha) with inserted organic fertilizers in sandy loam ((a), (c), (e)) and loamy sand ((b), (d), (f)) (Haplic Luvisol) soil.

with manure incorporated; comparing with the sandy soil. A lower amount of water infiltrated with incorporated organic fertilizers (40 t/ha sapropel and 60 t/ha manure fertilizer rates) could be observed, which reduced water runoff by 15\% (Table 2). Therefore, in order to avoid atmospheric precipitation leakage to deeper soil layers, it is recommended, as highlighted by many researchers, to enrich the incorporation of organic matter with organic fertilizers [33, 34].

Concerning the leaching of the main nutrients (nitrates, phosphorus and potassium) from the soil surface, different concentrations of fertilizers are noted depending on the fertilizers applied (Table 3). The annual distribution of precipitation was uneven over a three-year period, with the highest annual rainfall recorded in 2017. Thus, in the same year, the highest concentrations of the main elements in the infiltration water were detected.
Although the years were very uncontrasting in terms of rainfall, lower but not significant nitrate concentrations in soil with sapropel incorporated in the two types of soil were observed (Table 3). That suggests that sapropel can retain nitrates in soil, as confirmed by researcher Vasilyev [35] in his work.

Actually, during the first year of the experiment, a decreasing trend of the concentration in infiltrated water could be observed as compared to the control in which no fertilizer had been incorporated. That tendency was also evident during the third year of the experiment. When calculating the first-year correlations between the unfertilized and fertilized variants, a strong linear correlation was found with all fertilizers in the two types of soil $(r=0.99)$. The incorporation of organic matter into soil had a positive effect on the concentration of substances in the infiltrated 
water. Many researchers confirm the importance of fertilizer efficiency in the soils with very light texture, which prevents nutrient leaching from the arable soil layer to deeper layers [36, 37].

The phosphorus concentration was relatively low and did not depend on the composition of organic fertilizers incorporated in the soils. The phosphorus content equalled to approximately $0.12 \%$ of nitrogen and approximately $1.12 \%$ of potassium levels (Table 3). Phosphorus was mainly found on the soil surface - a biologically active layer of the soil profile. The penetration into deeper soil layers and groundwater was very poor. According to Tyla [13] and other researchers, phosphorus leaching does not exceed $1 \mathrm{~kg} / \mathrm{ha}$ per year, therefore, its concentration is not high in infiltrated water
(Fig. 2 (c), (d)).

\subsection{Leaching}

The greatest leaching of substances was observed in 2017, when the quantity of precipitation was abundant (948 mm) (Table 4).

Nitrate changes (Table 3) in lysimetric water show the highest concentration and leaching intensity at the same time compared to those of phosphorus (Fig. 2(c), (d)) or potassium (Fig. 2(e), (f)) elements. Once organic fertilizers are applied to soils and mineralization begins, inorganic nitrogen is released and absorbed by plants. However, the rate of mineralization is controlled by several factors,

Table 3. Average Annual Concentrations (mg/L) of Elements $\left(\mathrm{NO}_{3}{ }^{-}, \mathrm{P}\right.$ ir $\left.\mathrm{K}\right)$ in Leachates from Different Treatments of Fertilization in Sandy Soil and Loamy Sand Haplic Luvisol

\begin{tabular}{|c|c|c|c|c|c|c|c|c|c|c|c|c|}
\hline \multirow{2}{*}{ Fertilizers Year } & \multicolumn{3}{|c|}{ Control } & \multicolumn{3}{|c|}{ NPK } & \multicolumn{3}{|c|}{40 t/ha sapropel } & \multicolumn{3}{|c|}{60 t/ha manure } \\
\hline & $\mathrm{NO}_{3}$ & $\mathbf{P}$ & $\mathbf{K}$ & $\mathrm{NO}_{3}$ & $\mathbf{P}$ & $\mathbf{K}$ & $\mathrm{NO}_{3}$ & $\mathbf{P}$ & $\mathbf{K}$ & $\mathrm{NO}_{3}$ & $\mathbf{P}$ & $\mathbf{K}$ \\
\hline \multicolumn{13}{|l|}{ Sandy loam } \\
\hline 2016 & 33,43 & 0,04 & 3,9 & 20,32 & 0,03 & 4,2 & 26,74 & 0,03 & 4,7 & 26,22 & 0,02 & 5,1 \\
\hline 2017 & 38,54 & 0,05 & 3,9 & 29,59 & 0,04 & 4,5 & 27,26 & 0,04 & 4,1 & 30,26 & 0,05 & 3,9 \\
\hline 2018 & 21,92 & 0,02 & 2,1 & 23,4 & 0,02 & 2,5 & 21,49 & 0,02 & 2,3 & 24,88 & 0,02 & 2,3 \\
\hline Average amount & 31,3 & 0,04 & 3,3 & 24,4 & 0,03 & 3,7 & 25,2 & 0,03 & 3,7 & 27,1 & 0,03 & 3,8 \\
\hline $\mathrm{LSD}_{05}$ & 43,52 & 0,045 & 3,04 & 35,36 & 0,028 & 3,29 & 43,42 & 0,028 & 3,4 & 41,57 & 0,027 & 4,85 \\
\hline \multicolumn{13}{|l|}{ Loamy sand } \\
\hline 2016 & 17,49 & 0,03 & 4,7 & 17,19 & 0,2 & 4,3 & 14,23 & 0,05 & 3,8 & 21,59 & 0,06 & 4,5 \\
\hline 2017 & 40,88 & 0,05 & 4,1 & 32,72 & 0,05 & 3,9 & 25,06 & 0,05 & 4,4 & 36,43 & 0,05 & 4,1 \\
\hline 2018 & 13,54 & 0,02 & 1,7 & 16,01 & 0,03 & 1,7 & 12,31 & 0,03 & 2,1 & 14,4 & 0,02 & 1,7 \\
\hline Average amount & 24,0 & 0,03 & 3,5 & 22,0 & 0,09 & 3,3 & 17,2 & 0,04 & 3,4 & 24,1 & 0,04 & 3,4 \\
\hline $\mathrm{LSD}_{05}$ & 52,25 & 0,033 & 3,89 & 55,44 & 0,235 & 3,57 & 34,72 & 0,043 & 3,76 & 50,79 & 0,068 & 3,91 \\
\hline
\end{tabular}

NPK - Provita, phosphorite powder, potassium magnesia (Patenkali) fertilizers

$\mathrm{LSD}_{05}$ - least significant differences $(\mathrm{P}<0.05)$.

*significant differences compare with control (no-fertilised) treatment.

Table 4. Average Annual Elements Leaching (kg/ha) from Different Treatments of Fertilization

\begin{tabular}{|c|c|c|c|c|c|c|c|c|c|c|c|c|}
\hline \multirow{3}{*}{ Fertilization } & \multicolumn{12}{|c|}{ Season of the year } \\
\hline & \multicolumn{3}{|c|}{ Spring } & \multicolumn{3}{|c|}{ Summer } & \multicolumn{3}{|c|}{ Autumn } & \multicolumn{3}{|c|}{ Winter } \\
\hline & $\mathrm{NO}_{3}$ & $\mathbf{P}$ & $\mathbf{K}$ & $\mathrm{NO}_{3}$ & $\mathbf{P}$ & $\mathbf{K}$ & $\mathrm{NO}_{3}$ & $\mathbf{P}$ & $\mathbf{K}$ & $\mathrm{NO}_{3}$ & $\mathbf{P}$ & $\mathbf{K}$ \\
\hline \multicolumn{13}{|c|}{ Sandy loam Haplic Luvisol } \\
\hline Control & 8.68 & 0.05 & 3.34 & 2.31 & 0.01 & 4.30 & 10.57 & 0.06 & 3.01 & 10.40 & 0.05 & 3.38 \\
\hline NPK & 7.89 & $0.39 *$ & 3.41 & 2.14 & $0.02^{*}$ & 3.71 & 9.72 & 0.07 & 2.91 & 9.57 & $0.07^{*}$ & 3.21 \\
\hline 40 t/ha sapropel & 6.58 & 0.10 & 3.37 & 2.31 & $0.02^{*}$ & 3.48 & $6.05^{*}$ & 0.07 & 3.11 & 8.01 & $0.06^{*}$ & 3.63 \\
\hline $60 \mathrm{t} / \mathrm{ha}$ manure & 8.54 & 0.14 & 3.27 & 2.35 & 0.01 & 2.91 & 10.08 & 0.06 & 2.86 & 11.20 & 0.05 & 3.42 \\
\hline $\mathrm{LSD}_{05}$ & 3.33 & 0.16 & 0.68 & 0.28 & 0.01 & 1.36 & 3.74 & 0.02 & 0.5 & 3.19 & 0.01 & 0.44 \\
\hline \multicolumn{13}{|c|}{ Loamy sand Haplic Luvisol } \\
\hline Control & 10.60 & 0.07 & 3.57 & 3.72 & 0.01 & 1.91 & 14.74 & 0.08 & 6.57 & 12.69 & 0.03 & 3.44 \\
\hline NPK & 8.74 & $0.03^{*}$ & $4.61^{*}$ & 3.32 & $0.02^{*}$ & $4.77^{*}$ & 10.57 & $0.09^{*}$ & 7.55 & 9.97 & 0.05 & 3.86 \\
\hline 40 t/ha sapropel & 8.16 & $0.03^{*}$ & 5.16 & 2.98 & $0.02^{*}$ & $5.16^{*}$ & $9.20^{*}$ & $0.07^{*}$ & $8.42^{*}$ & 13.22 & 0.04 & 4.39 \\
\hline $60 \mathrm{t} / \mathrm{ha}$ manure & 10.31 & $0.03^{*}$ & $4.63^{*}$ & 2.66 & 0.02 & $3.97^{*}$ & 13.17 & $0.07^{*}$ & 7.75 & 10.68 & 0.04 & 4.11 \\
\hline $\mathrm{LSD}_{05}$ & 4.13 & 0.03 & 0.75 & 1.09 & 0.01 & 2.00 & 4.55 & 0.01 & 1.83 & 3.64 & 0.03 & 0.48 \\
\hline
\end{tabular}

NPK - Provita, phosphorite powder, potassium magnesia (Patenkali) fertilizers

$\mathrm{LSD}_{05}$ - least significant differences $(\mathrm{P}<0.05)$.

*significant differences compare with control (no-fertilised) treatment. 
including agricultural management, soil properties, temperature, and water content, as well as the type of organic fertilizer

Nitrogen from many organic fertilizers is the slow-release and organically bound, and this process finally increases the long-term efficiency of organic fertilizers, better soil agrochemical composition, furthermore during the amount of precipitation have less leaching losses [30, 44]

Talking about leahing quantity, the studies show that less nitrogen $\left(\mathrm{N}-\mathrm{NO}_{3}\right)$ leaching, in sandy loam (2.14-2.35 kg/ha) and in loamy sand (2.66-3.72 kg/ha), is recorded in summer, because filtration of precipitation during this period is negligible, due to intensive use of water by plants and hydrothermal regime (Table 3, Table 4) [30-31].
The correlation analysis of precipitation and nitrate leaching losses shows a direct dependence of nitrate leaching on the levels of rainfall (correlation for sandy loam and loamy sand soils ranged between 0.86 and 0.99) (Fig. 3 (a), (b)) and this improve that hydrothermal conditions played the main role in filtration of atmospheric precipitation.

A very weak correlation (sandy loam $-\mathrm{r}=0.23$, loamy sand - $r=0.29$ ) of the incorporated sapropel fertilizer should be noted, therefore, it can be stated that nitrate leaching was not related to the prevailing rainfall of the three $(2016,2017,2018)$ experimental years, but to its quantity in 2017 (Fig. 4 (a), (b)). In 2017, the correlations in different soil types varied: a strong positive correla-
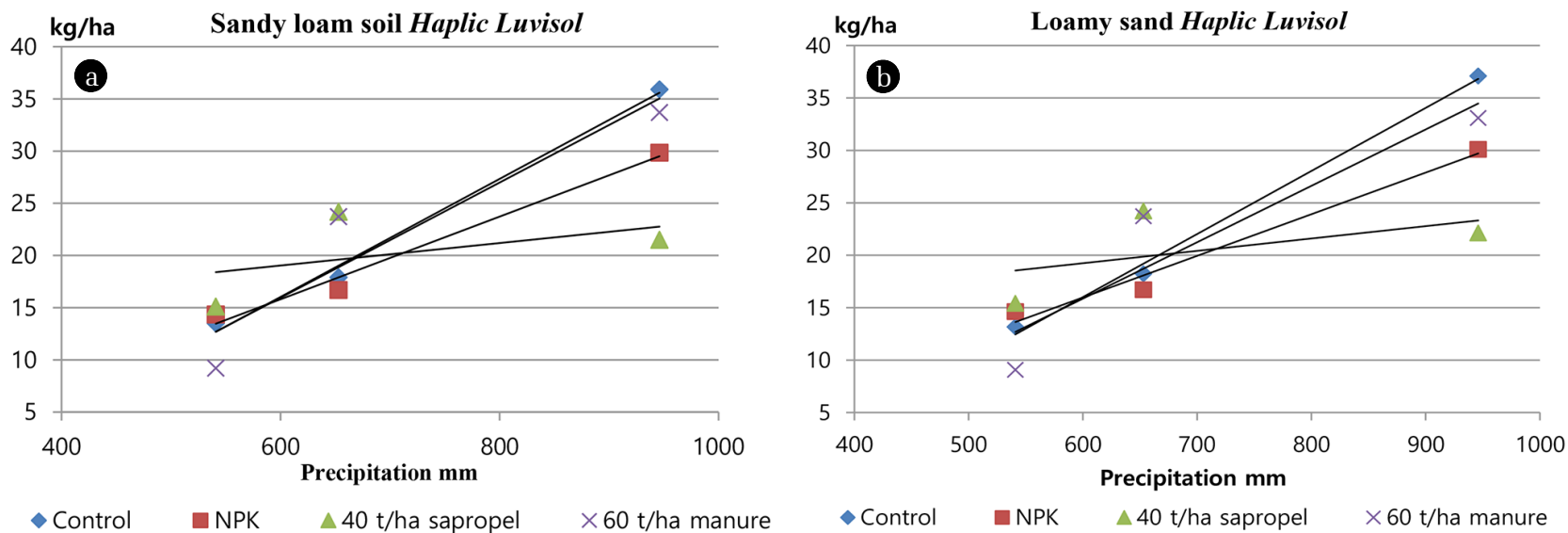

Note: NPK - Provita, phosphorite powder, potassium magnesia (Patenkali) fertilizers

(a) $\mathrm{y}$ (control) $=0.0565 \mathrm{x}-17.893, \mathrm{R}^{2}=0.9928 ; \mathrm{y}(\mathrm{NPK})=0.0396 \mathrm{x}-7.9514, \mathrm{R}^{2}=0.9832 ; \mathrm{y}(40 \mathrm{t} /$ ha sapropel $)=0.0108 \mathrm{x}+12.582$, $\mathrm{R}^{2}=0.233 ; \mathrm{y}(60 \mathrm{t} / \mathrm{ha}$ manure $)=0,0551 \mathrm{x}-17.134, \mathrm{R}^{2}=0.8768$.

(b) $\mathrm{y}\left(\right.$ control) $=0.0601 \mathrm{x}-20.08, \mathrm{R}^{2}=0.9952$, y $(\mathrm{NPK})=0,0397 \mathrm{x}-7,8555 ; \mathrm{R}^{2}=0.9784 ; \mathrm{y}(40 \mathrm{t} /$ ha sapropel $)=0.0118 \mathrm{x}+12.142$; $\mathrm{R}^{2}=0.2896 ; \mathrm{y}(60 \mathrm{t} / \mathrm{ha}$ manure $)=0.0538 \mathrm{x}-16.406, \mathrm{R}^{2}=0.8636$

Fig. 3. Correlation relationships between nitrate leaching (kg/ha) $(2016 ; 2017 ; 2018)$ and annual atmospheric precipitation amounts (mm) in sandy loam (a) (Haplic Luvisol) and loamy sand (b) soils.
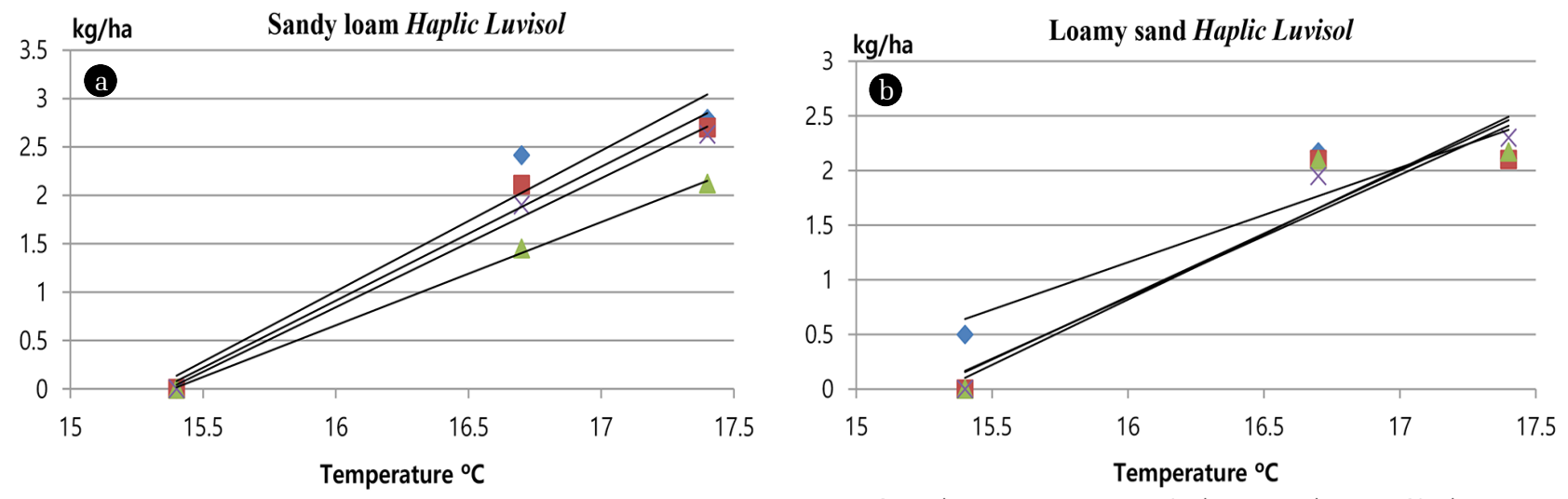

$\checkmark$ Control $\quad$ NPK $\triangle 40 \mathrm{t}$ /ha sapropel $\times 60 \mathrm{t} /$ ha manure $\quad$ Control $\quad \mathrm{NPK} \quad \triangle 40 \mathrm{t} / \mathrm{ha}$ sapropel $\times 60 \mathrm{t} / \mathrm{ha}$ manure

Note: NPK - Provita, phosphorite powder, potassium magnesia (Patenkali) fertilizers

(a) $\mathrm{y}($ Control $)=1.4533 \mathrm{x}-22.245, \mathrm{R}^{2}=0.9491 ; \mathrm{y}(\mathrm{NPK})=1.067 \mathrm{x}-16,415, \mathrm{R}^{2}=0.9986$; $\mathrm{y}(40 \mathrm{t} /$ ha sapropel $)=1.3845 \mathrm{x}-21.24$, $\mathrm{R}^{2}=0.9798 ; \mathrm{y}(60 \mathrm{t} / \mathrm{ha}$ manure $)=1.3335 \mathrm{x}-20.493, \mathrm{R}^{2}=0.9936$.

(b) y (Control) $=0.8655 \mathrm{x}-12.688, \mathrm{R}^{2}=0.8598$; $\mathrm{y}(\mathrm{NPK})=1.1214 \mathrm{x}-17.102, \mathrm{R}^{2}=0.8811 ; \mathrm{y}(40 \mathrm{t} /$ ha sapropel $)=1.1519 \mathrm{x}-17.584$, $\mathrm{R}^{2}=0.8988 ; \mathrm{y}(60 \mathrm{t} / \mathrm{ha}$ manure $)=1.1942 \mathrm{x}-18.287, \mathrm{R}^{2}=0.9564$.

Fig. 4. Correlation relationships between of 2017 summer nitrate leaching (kg/ha) and temperature (mm) in sandy loam (a) and loamy sand (b) Haplic Luvisol soils. 
tion $(\mathrm{r}=0.93)$ was observed in sandy loam, and a strong negative one was recorded in loamy sand soil ( $\mathrm{r}=-0.94)$, which suggests that sapropel fertilizer mineralises nitrogen at a lower rate in light loam soils with higher organic matter content ensuring low nitrate losses [23, 24, 38].

The summer season of 2017 was very rainy with average temperatures 1-2 degrees lower than SCN. Thus, calculating the correlations between the prevailing temperature and the nitrate leaching yielded a strong positive relationship (Fig. 4 S1, S2). In a cooler summer with heavy rainfall, the soil covered with agricultural crops may demonstrate a lower degree of absorbing free-moving nitrate ions, resulting in greater losses in light sandy loam and loamy sand soils [39].

Potassium, similarly to nitrate nitrogen, is distinguished for high mobility and is therefore easily leached out in larger quantities. Based on the results obtained, the quantities of potassium leaching (Fig. 2(c), (d)) were relatively smaller than those of nitrates (Fig. 2 (a), (b)). The distribution of leaching was not uniform: similar quantities of leaching with different types of fertilizers (2.91-4.30 $\mathrm{kg} / \mathrm{ha}$ ) could be observed in sandy loam soil during the three years and different seasons; higher potassium losses in loamy sand soil were identified for all seasons (3.97-7.55 kg/ha) (Table 4). Although the highest amount of potassium was added to the manure application, the correlations between the leaching dependence on temperature $(\mathrm{r}=0.35)$ and the quantity of infiltrated water $(\mathrm{r}=0.28)$ were very weak. Manure fertilization tends to reduce the quantities of potassium leaching, and due to its ability to release nutrients gradually, soil is not depleted of potassium over several years [19]. Potassium is much more efficiently used in moist soil, while the efficiency of fertilizers applied is reduced, and conversely, in the case of low-organic-matter soils with lower moisture content, the fertilizers incorporated are more effective thus the losses observed are lower in sandy loam soils, compared to those in light loam soils with more numerous clay particles [20-22].

The mobility of phosphorus in soil is very limited. Very little phosphorus is leached from soil in Lithuania (only about $1 \mathrm{~kg} / \mathrm{ha}$ ) $[39,40]$. Our experiments showed similar results. Phosphorus concentrations in lysimetric water ranged from 0.02 to $0.06 \mathrm{mg} \mathrm{L}$, and leaching losses averaged $0.01-0.39 \mathrm{~kg} / \mathrm{ha}$. This indicates that the movement of soil phosphorus with drainage runoff was not accelerated due to more abundant precipitation.

According to various researchers, the concentration of phosphorus in the drainage water in unfertilised and phosphorus-fertilized arable soils and pastures is insignificant and it is less than 0.7 $\mathrm{mg} / \mathrm{L}$ (Table 4). Such insignificant amounts of phosphorus in drainage water result due to the fact that phosphorus form poorly soluble compounds with other elements [42].

Although the phosphorus content in the two types of soil was described as high and very high (203-244 mg/kg), due to low phosphorus mobility and solubility, its leaching losses were low (Table 4).

Significantly high phosphorus leaching losses in sandy loam soil were observed with NPK fertilizer mixtures $(0.02-0.39 \mathrm{~kg} / \mathrm{ha})$ incorporated; in loam soil the situation was similar (0.02-0.09 kg/ha) (Table 4). The mineral fertilizer mixture was spread every year in spring on the two types of soil; however, the quantities of leaching in sandy loam in spring should be noted. Joniškèlis' researchers have been reporting since 1965 that at maximum $\mathrm{pH}$ between 4.5 and 5.5, the efficiency of phosphorite powder as a fertilizer is optimal on light sandy loam and light loam soils. This is confirmed by our results: with warmer weather, more rainfall and proper $\mathrm{pH}$ of the soil, the performance of phosphorus fertilizer was better, which led to higher leaching losses of substances without the element having been used by the plant.

The maximum leaching loss of phosphorus in spring with NPK fertilizers incorporated should be noted. It should be mentioned that the mechanical composition of soil plays an important role in the sorption of phosphorus compounds, and it determines the downward movement of compounds in soil.

The fact that phosphorite powder is a substance that is poorly soluble in soil negates the significantly greatest amount of leaching. An important aspect of phosphorus compound sorption is the mechanical composition of soil, which determines the downward movement of compounds in soil.

\section{Conclusions}

Due to low organic matter content in sandy loam, after organic matter incorporation the amount of rainfall runoff from the soil arable layer remained higher by $7-19 \%$, whereas precipitation percolation to deeper soil layers in loamy sand soil with higher content of organic matter and clay particles decreased from 2 to $6 \%$. Fertilizing with sapropel at $40 \mathrm{t} /$ ha rate reduced nitrate leaching losses in the two types of soil (2 to $52 \%$ in sandy loam, and 9 to $39 \%$ in loamy sand). The quantity of nitrate leaching indicated a strong positive correlation with air temperature. Nitrate infiltration increased proportionally with decreasing temperature. With the manure application rate of $60 \mathrm{t} / \mathrm{ha}$, the highest amount of potassium was applied to the plots, however, the three-year results showed a decreasing trend in potassium loss. Manure fertilization showed a tendency to release the element gradually, which would result in a long-term supply of potassium in the soil. Significantly high phosphorus leaching losses were found in the two types of soil with N P K fertilizer mixture $(0.02-0.39 \mathrm{~kg} / \mathrm{ha}$ in sandy loam, and $0.02-0.09 \mathrm{~kg} / \mathrm{ha}$ in loamy sand). Such phosphorus losses in light sandy loam soil were determined by the mechanical composition and acidity of the soil $(\mathrm{pH}=5.2)$.

\section{Author Contributions}

B.A. (Ph.D. student) conducted all the experiments and the article analysis under the joint supervision of B.E (Ph.D).

\section{References}

1. Ahlvik L, Ekholm P, Hyytiäinen K, Pitkänen H. An economic-ecological model to evaluate impacts of nutrient abatement in the Baltic Sea. Environ. Model. Softw. 2014;55:164-175.

2. Randall P. Arsenic encapsulation using Portland cement with ferrous sulfate/lime and Terra-Bond (TM) technologies Microcharacterization and leaching studies. Sci. Total Environ. 2012;420:300-312. 
3. Qaswar M, Huang J, Ahmed W, et al. Substitution of Inorganic Nitrogen Fertilizer with Green Manure (GM) Increased Yield Stability by Improving C Input and Nitrogen Recovery Efficiency in Rice Based Cropping System. Agronomy 2018;9(10):609.

4. Paradelo, Moldrup M, Moldrup N, et al. Prediction of the glyphosate sorption coefficient across two loamy agricultural fields. Geoderma 2015;259:224-232.

5. Žèkaitė V, Staugaitis G, Arbačiauskas J, et al. Influence of organic fertilization on npk balance and nutrients dynamics in the soil. Zemes ukio mokslai. 2015;22(1):44-55.

6. Halim MA, Majumder RK, Zaman MN. Paddy soil heavy metal contamination and uptake in rice plants from the adjacent area of Barapukuria coal mine, northwest Bangladesh. Arab. J. Geosci. 2015;8(6):3391-3401.

7. Lori M, Symnaczik S, Mäder P, de Deyn G, Gattinger A. Organic farming enhances soil microbial abundance and activity - A meta-analysis and meta-regression. PLoS One. 2017;12(7): e0180442.

8. Feber RE, Johnson PJ, Bell JR, et al. Organic Farming: Biodiversity Impacts Can Depend on Dispersal Characteristics and Landscape Context. PLOS ONE. 2015;10:e0135921.

9. Delin S, Stenberg M. Effect of nitrogen fertilisation on nitrate leaching in relation to grain yield response on loamy sand in Sweden. Europ. J. Agronomy. 2014;52:291-296.

10. Doltra J, Jørgen O. The role of catch crop in the ecological intensification of spring cereals in organic farming under Nordic climate. Europ. J. Agronomy. 2013;44:98-108.

11. Interagency Climate Adaptation Team, Adapting to Climate Change in Minnesota, Minnesota Pollution Control Agency; Document Number: p-gen4 -0; Interagency Climate Adaptation Team: MN, USA. 2017.

12. Kim K, Kim B; Eum J, et al. Impacts of land use change and summer monsoon on nutrients and sediment exports from an agricultural catchment. Water 2018;10(5):544

13. Tyla A, Rimšelis J, Šleinys R. Leaching of Mutrient Matter of Plants in Different Soils, Dotnuva, Akademija. 1997.p. 24 (in Lithuanian with English summary).

14. Zhang TQ, Mackenzie AF, Liang BC. Nitrate leaching from residual fertilizer $\mathrm{N}$ after spring thaw in two corn agro-ecosystems. Can. J. Soil Sci. 2004;84:477-480.

15. Ju XT, Kou CL, Zhang FS, Christie P. Nitrogen balance and groundwater nitrate contamination: comparison among three intensive cropping systems on the North China Plain. Environ. Pollut. 2006;143:117-125.

16. Ju XT, Liu XJ, Zhang FS, Roelcke M. Nitrogen fertilization, soil nitrate accumulation, and policy ecommendations in several agricultural regions of China. AMBIO: J. Hum. Environ. 2004;33(6):300-305.

17. Yadav SN. Formulation and estimation of nitrate-nitrogen leaching from corn cultivation. J. Environ. Qual. 1997;26:808-814.

18. Zhang F, Wang J, Wang XX. Recognizing the relationship between spatial patterns in water quality and land-use/cover types: A case study of the Jinghe Oasis in Xinjiang, China. Water 2018;10(5):646.

19. Geng Y, Cao G, Wang L, Wang S. Effects of equal chemical fertilizer substitutions with organic manure on yield, dry matter, and nitrogen uptake of spring maize and soil nitrogen distribution. PLoS One. 2019;14(7):e0219512.

20. Askegaard M, Seges J, Eriksen I. Potassium retention and leaching in an organic crop rotation on loamy sand as affected by contrasting potassium budgets. Soil Use Manag. 2016;16: 200-205.

21. Mendes WC, Júnior JA, da Cunha PCR, et al. Potassium leaching in different soils as a function of irrigation depths. R. Bras. Eng. Agríc. Ambiental. 2016;20(11):972-977.

22. Sardans J, Peñuelas J. Potassium: a neglected nutrient in global change. Glob. Ecol. Biogeogr. 2015;24:261-275.

23. Plotnikov AM, Sozinov AV. Effect of sapropels on yield of grain crops and acidity of the leached chernozem. Agriculture 2016;4(46):61-65.

24. Ivanova T, Pavlov N, Kerechanina E. The analyses of mimiralization and transformation of substances including sapropels. Analitika 2014;6(19):62-73.

25. Bakšienė E, Ražukas A, Asakaviciute R, et al. Effects of ecological farming systems and five-year crop rotations on crop productivity and properties of Haplic Luvisol. Journal of Food Agriculture and Environment. 2013;11:1137-1142.

26. Li Y, Li J, Gao L. Irrigation has more influence than fertilization on leaching water quality and the potential environmental risk in excessively fertilized vegetable soils. PLoS One. 2018;13(9):e0204570.

27. Meilutytė -Barauskienė D, Kriaučiūnienė J, Kovalenkovienė M. Impact of climate change on runoff of the Lithuanian rivers. Modern climate change models, statistical methods and hydrological modelling. Saarbrücken, Germany: LAP LAMBERT Academic Publishing; 2010. p. 55.

28. Galvonaitė A, Kilpys J, Kitrienè Z, Valiukas D. Climate averages for Lithuania 1981-2010. Climatology Division at Lithuanian. Hydrometeorological Lithuanian Climate Atlas. Vilnius: Lithuanian Hydrometeorological Service. 2013.

29. Raudonius S. Application of statistics in plant and crop research: important issues. Zemdirbyste. 2017;104(4):377-382.

30. Mclsaac G. Agricultural nutrient management in the Great Lakes region. In: Sustainable Agriculture. Ed. Ch. Jakobsson. Sweden: Uppsala University. 2012. p. 102-106.

31. Tripolskaja L, Booth CA, Fullen MA. Leaching of Nutrients in Luvisol as Affected by Catch Crops and Straw. Glob. J. Sci. Front. Res. Agric. Vet. 2013;13(12):17-27.

32. Murphy B. Key soil functional properties affected by soil organic matter - evidence from published literature. IOP Conference Series: Earth and Environmental Science. Soil Change Matters. 2014;25:012008.

33. Bandyopadhyay MM, Misra AK, Ghosh PK, Hati KM. Effect of integrated use of farmyard manure and chemical fertilizers on soil physical properties and productivity of soybean. Soil Till Res. 2010;110:115-125.

34. Nayak T, Patel T, Bajpai RK. Influence of organic and inorganic fertilization on soil physical properties in a Vertisol under rice. The Ecoscan. 2015;9(1-2):71-74.

35. Vasiliev AA. Effect of sapropels on potato yield and fertility of leached chernozem. Cand. Agr. Sci. 2014;635(21):3-9.

36. Diacono MA, Montemurro FA. Review Effectiveness of Organic Wastes as Fertilizers and Amendments in Salt-Affected Soils. Agriculture 2015;5:221-230. 
37. Martínez-Alcántara B, Martínez-Cuenca MR, Bermejo A, Legaz F, Quiñones A. Liquid Organic Fertilizers for Sustainable Agriculture: Nutrient Uptake of Organic versus Mineral Fertilizers in Citrus Trees. PLoS One. 2016;11:e0161619.

38. Blečic A, Railić B, Dubljević R, Mitrović B, Spalevic V. Application Of Sapropel In Agricultural Production. Agric. Forestry 2014;60:243-250.

39. Fraters D, Leeuwen T, Boumans L, Reijs J. Use of long-term monitoring data to derive a relationship between nitrogen surplus and nitrate leaching for grassland and arable land on well-drained sandy soils in the Netherlands. Acta. Agric. Scand. $B$ Soil Plant Sci. 2015;e65:144-154.

40. Tripolskaja L, Mašauskas V, Adomaitis T, Karčiauskienė D, Vaišvila Z. Management of agroecosystem components. Results of Long-term agrochemical experiments. Lithuania, Vilnius. 2010.p. 567.

41. Pengerud A, Stålnacke P, Bechmann M, et al. Temporal trends in phosphorus concentrations and losses from agricultural catchments in the Nordic and Baltic countries. Acta. Agric. Scand. B Soil Plant Sci. 2015;65:173-185.

42. Azevedo RP, Salcedo IH, Lima PA, Fraga VS, Lana RMQ. Mobility of phosphorus from organic and inorganic source materials in a sandy soil. Int. J. Recycl. Org. Waste Agricult. 2018;7:153-163.

43. Fan XH, Li YC. Nitrogen release from slow-release fertilizers as affected by soil type and temperature. Soil Sci. Soc. Am. J. 2010;74:1635-1641.

44. Dessureault-Rompré J, Zebarth BJ, Burton DL, et al. Relationships among mineralizable soil nitrogen, soil properties, and climatic indices. Soil Sci. Soc. Am. J. 2010;74:12181227. 